\title{
プラント建設プロジェクトの成功に影響する 組織のレジリエンス向上とプロジェクトマネジメント施策との関係 CORRELATION BETWEEN THE MEASURES OF PROJECT MANAGEMENT AND THE ENHANCEMENT OF RESILIENCE OF ORGANIZATION FOR THE SUCCESS OF PLANT CONSTRUCTION PROJECTS
}

\author{
安部和 秀*, 高野研一** \\ Kazuhide ABE and Kenichi TAKANO
}

\begin{abstract}
This research aims to prove that the measures of project management lead the enhancement of resilience of organizations for the success of plant construction projects that entail a lot of risks due to their huge size and complicated formation of organizations. Multivariate analysis on the data obtained through the Internet questionnaire proved that the measures of project management make the organizations and people involved in a project attentive, and the attentiveness affects resilience, and the resilience contributes to the success of projects.
\end{abstract}

Keywords : Project M anagement, Attentive, resilience, Questionnaire, Structural Equation M odeling プロジェクトマネジメント，マインドフル，レジリエンス，アンケート調査，共分散構造分析

1

はじめに

昨今のプラント建設は建造物の巨大化に伴いプロジェクト期間中 に扱う資機材及び管理的データ量が増大の一途を辿っている。その ため一社単独では建設プロジェクトを遂行するための人員が足りず, またプロジェクトのリスクを一社で全て負いきれない状況が発生し ている。これにより, ジョイントベンチャー（JV）による複数社で のプロジェクト遂行が増える傾向にある。プロジェクトに関与する 組織は増加し，かつ多彩になり，組織間の調整の難易度が上がって いる。しかしながら，プロジェクトの期間や予算はプロジェクトの 巨大化に比例することなく, 峳しい競争環境の下, 極めて厳しい納 期と予算での遂行が求められており, プロジェクトメンバー (注 1) は過去に経験したことのない大量の資機材とデータ量の流れをコン トロールしなくてはならない状況にある。

また，プロジェクト遂行が容易な場所での計画は減り，極地，政 情不安な国等, 地政学的な配慮を必要とする場所でのプロジェクト が増えている。シェールガス革命と呼ばれる，新エネルギー資源の 台頭はエネルギー資源国間の力関係に影響を及ぼし, 先の読み辛い 状況下，プラント建設に対する要求は厳しさを増している。

\section{1 現状の問題}

多くの不確実性を抱える巨大プロジェクトでは, 小さなミスであ っても，その影響度合いが極めて大きくなる場合があり，失敗の連 鎖につながるケースが増えてきている。大量のデータを限られた人
員でコントロールすることによる負担増加なども影響し，十分な管 理機能が働かずミスにつながるケースもある。また，JVでのプロジ エクト遂行は, 異なる組織文化の対立, 不慣れな他社の管理手法の 利用などにより更に問題の複雑性が増すことになる。

このようなプロジェクト遂行環境では，大きな損失につながる想 定外の事象がいつ起きてもおかしくない。したがって, プロジェク 卜の初期に立てた計画と遂行中の実績の比較に基づき必要な対応を 取るような計画重視の施策に加えて，想定外の事象発生時における 組織のレジリエンス（注 2) を向上させるための施策，あるいは想 定外の事象をその影響がまだ小さい段階で発見し迅速に対応するた めの施策が必要である

\section{2 本研究の目的と対象}

本研究の目的は，プラント建設プロジェクトにおいてプロジェク トマネジメントの施策がプロジェクトに関わる組織のレジリエンス の向上につながることを立証することである。プロジェクトに関わ る組織と人が自律的に判断し行動することを重視して仮説を立てた。 本論文で着目した判断力と行動力の発揮は，プラントエンジニアリ ング系，土木・建築系プロジェクトといったプロジェクトの役務対 象や，必要とされる専門技術の違いに寄らず，プロジェクトに関わ る組織と人が持つべき基本的能力を対象としている。

\section{3 本研究の範囲}

本研究で扱うプロジェクトマネジメントは，プラントオーナーと
* 慶應義塾大学大学院システムデザイン・マネジメント研究科 大学院生・システムデザイン・マネジメント修

** 慶應義塾大学大学院システムデザイン・マネジメント研究科 教授·工博
Grad. Stud. Graduate School of System Design and Management, Keio University, M.System Design and Management

Prof., Graduate School of System Design and Management, Keio University, Dr.Eng. 
のプロジェクト契約（主契約）を結んだ元請のプロジェクトマネジ メント組織（以下, PMT (Project Management Team) (注 3) と呼称 する）の立場で, その主契約に関連して契約が発生する組織を対象 として, 主契約で求められる品質, コスト, 納期を満たすためのプ ロジェクトを推進させるための施策である。したがって, 下請 (注 4) や資機材を提供する協力会社に PMT が存在する場合は, それらを含 む。組織内にプロジェクトマネジメント機能を必要とせず，通常の 組織運営でプロジェクトに関与できる組織は研究対象外とする。元 請は複数の企業による JV である場合を含む。本研究で扱う範囲の 典型的な組織の関係を図 1 に示した。

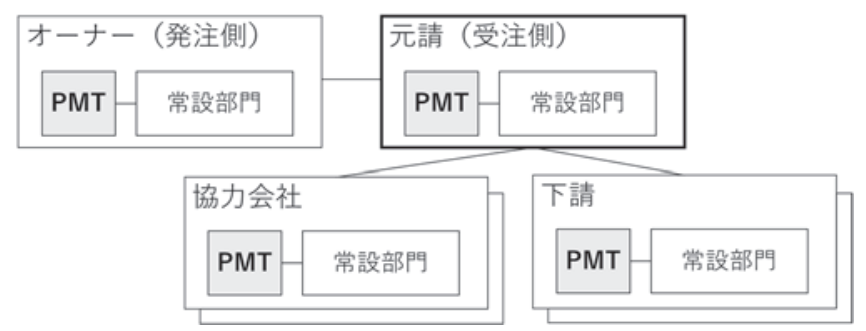

Fig.1 PMT Covered by This Research

\section{4 先行研究調査}

Longstaff ら 1) は最近のプロジェクトマネジメント施策が危機一 の備え重視型から, 備えと復旧の統合型へ移行する傾向にあると述 ベ, レジリエンス強化への取り組みの増加を示唆している。また, 復 旧を必要とする元の機能の維持のために, 個々の遂行手順は変更さ れているかもしれないと述べ, 単に元の状態に戻すのではないこと を明確にしている。すなわちレジリエンスの発揮には, 定められた 手順に従うのではなく, 必要とされる機能を見極め, 限られた資源 で復旧のための手順を迅速に見つけ出す能力が必要なのである。

Weickら 2) は, 予断を許さない, 緊張下に置かれた状況であって も高い信頼性と成果を発揮する組織の研究から, そのような組織が, 「失敗から学ぶ」「単純化を許さない」「操業の現場を重視する」「復 旧能力を高める」「専門知識を尊重する」という 5 つの特徵を持つ, プロジェクト遂行組織が自ら持っているリスク認識に基づく行動 (以下，マインドフル（注 5) な行動と呼称する）により, 組織の信 頼性を高く保っていることを見出した。すなわちそのような組織に は通常の業務遂行手順に合致しない事象に対して適切な行動を迅速 に見つけ出し, かつ実行する能力が備わっており, その能力は Longstaff らの述べるレジリエンスの発揮に必要な能力と通じると 理解した。

\section{2 仮説}

本研究では, 現在のプラント建設プロジェクト遂行においてもマ インドフルな行動がプロジェクトの成功のために効果的であり, か つそのような行動を生み出すプロジェクトマネジメント施策が存在 すると考え，次のような仮説を立てた。

仮説：プロジェクトマネジメントの施策がプロジェクト遂行組織の マインドフルな行動を促進するものであれば，失敗に至る可能性の あるリスクを多く抱えるプロジェクトであっても組織のレジリエン スを発揮して成功に導くことが可能である（図 2 参照)。

\section{プロジェクト マネジメント マネジメント

Fig. 2 Hypothesis for project success

\section{3 仮説の検証}

\section{1 アンケート調査（インターネット調査による）}

3.1.1 アンケートの作成

アンケートは，以下のような構成とした。回答者の属性および自 由記述はカテゴリ一選択あるいは記述式とした。それ以外の調查項 目はリッカート尺度に乗っ取り，「非常によく当てはまる」「当ては まる」少し当てはまる」「あまり当てはまらない」当てはまらない」 「全く当てはまらない」の 6 件法を用いた。プロジェクトマネジメ ント施策に関しては，PMBOK@ガイド3)の10 の知識領域にまたがる ように選択して設定した。また，アンケート項目に正しく答えやす いかどうかを確認するために，プロジェクトマネジメント経験者 2 名が内容のレビューを行った。

質問項目を表 1 と表 2 に示す。表 2 には「プロジェクトマネジメ ント施策」の因子分析後の負荷量も示した。なお，因子分析におい て十分な因子負荷量を示さなかった 1 項目は除外してある。

Table1 Questions of Internet questionnaire (1)

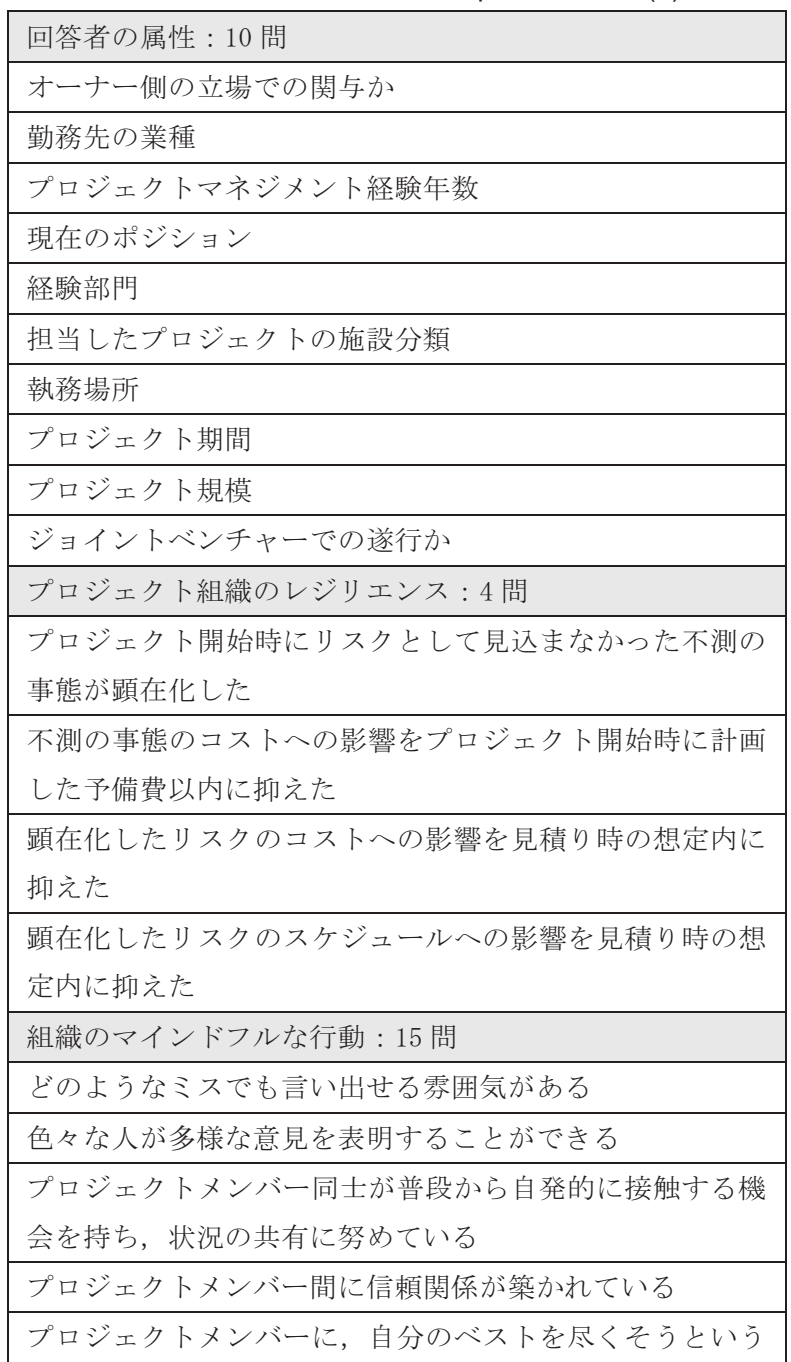




\begin{tabular}{|c|}
\hline 使命感がある \\
\hline $\begin{array}{l}\text { 間一髪で損失 (コスト,スケジュール) を免れた場合, それ } \\
\text { を現実的な「劦威」と考え，その情報を共有している }\end{array}$ \\
\hline $\begin{array}{l}\text { ミスなどを届け出て作業を中断させたとしても非難される } \\
\text { ことはない }\end{array}$ \\
\hline $\begin{array}{l}\text { 各人が自分の職務範囲を超えて, プロジェクト遂行で求め } \\
\text { られる行動に精通している }\end{array}$ \\
\hline 各自の能力を超えた任務への挑戦が奨励される \\
\hline $\begin{array}{l}\text { 不測の事態が起きた時，地位に関係なく，ふさわしい人間 } \\
\text { が意思決定を行う }\end{array}$ \\
\hline $\begin{array}{l}\text { 間一髪で損失 (コスト,スケジュール) を免れた場合, その } \\
\text { 経験と教訓を反映するよう迅速に手順を見直す }\end{array}$ \\
\hline お互いの意見を尊重し注意深く耳を傾ける \\
\hline $\begin{array}{l}\text { 不測の事態が発生した時, すぐに必要な経営資源を手当て } \\
\text { できる }\end{array}$ \\
\hline $\begin{array}{l}\text { プロジェクトメンバーは知識を状況に応じて柔軟に活用す } \\
\text { る能力に長けている }\end{array}$ \\
\hline $\begin{array}{l}\text { プロジェクトメンバーはお互いの職務の専門性を尊重して } \\
\text { いる }\end{array}$ \\
\hline プロジェクトの特性・成否の確認 : 4 問 \\
\hline プロジェクトは求められている品質を満たした \\
\hline プロジェクトは求められているコスト内に納まった \\
\hline プロジェクトは求められているスケジュール内で完了した \\
\hline 全体としてプロジェクトは成功した \\
\hline プロジェクトの成功に関する自由記述 : 3 問 \\
\hline $\begin{array}{l}\text { プロジェクトを成功させる上で最も重要なことは何だと思 } \\
\text { うか }\end{array}$ \\
\hline $\begin{array}{l}\text { プロジェクト遂行中，成功に対するモチベーションが高ま } \\
\text { るきっかけ（要因）は何か }\end{array}$ \\
\hline 緊急対応が必要な時に, 意外と効果のあった施策は何か \\
\hline
\end{tabular}

Table2 Questions of Internet questionnaire (2)

\begin{tabular}{|c|c|c|c|c|c|}
\hline \multirow{3}{*}{$\begin{array}{l}\text { 質 } \\
\text { 問 }\end{array}$} & \multicolumn{5}{|c|}{ プロジェクトマネジメント施策の確認 } \\
\hline & \multicolumn{5}{|c|}{ 因子負荷量 (5 因子) } \\
\hline & 1 & 2 & 3 & 4 & 5 \\
\hline \multirow[t]{2}{*}{1} & \multicolumn{5}{|c|}{$\begin{array}{l}\text { 充実したプロジェクトマネジメントスキル育成プロ } \\
\text { グラムを利用できる }\end{array}$} \\
\hline & .657 & .116 & -.142 & .189 & .013 \\
\hline \multirow[t]{2}{*}{2} & \multicolumn{5}{|c|}{$\begin{array}{l}\text { プロジェクトの状況を第三者（内部，外部）がチェ } \\
\text { ック寸る機能がある }\end{array}$} \\
\hline & .602 & -.077 & .105 & -.117 & .268 \\
\hline \multirow[t]{2}{*}{3} & \multicolumn{5}{|c|}{$\begin{array}{l}\text { 様々な国籍のプロジェクト関係者が平等に意見を出 } \\
\text { す仕組みがある }\end{array}$} \\
\hline & .590 & .182 & .110 & .080 & -.289 \\
\hline \multirow[t]{2}{*}{4} & \multicolumn{5}{|c|}{$\begin{array}{l}\text { 外部調達において, 協力会社のパフォーマンス評価に } \\
\text { 必要な情報を共有する仕組みがある }\end{array}$} \\
\hline & .580 & .000 & .016 & .092 & .215 \\
\hline \multirow[t]{2}{*}{5} & \multicolumn{5}{|c|}{$\begin{array}{l}\text { 機材費の変動を予測するために常に外部の専門家の } \\
\text { 見解を入手している }\end{array}$} \\
\hline & .551 & -.165 & .464 & .082 & -.077 \\
\hline
\end{tabular}

\begin{tabular}{|c|c|c|c|c|c|}
\hline \multirow[t]{2}{*}{6} & \multicolumn{5}{|c|}{$\begin{array}{l}\text { 不測の事態に際して情報は特定のマネジメント層の } \\
\text { みに知らされる }\end{array}$} \\
\hline & .478 & .167 & .181 & -.081 & -.074 \\
\hline \multirow[t]{2}{*}{7} & \multicolumn{5}{|c|}{$\begin{array}{l}\text { 複数のステークホルダー間での非公式な意見交換が } \\
\text { 活発に行われる }\end{array}$} \\
\hline & .390 & .067 & .003 & .320 & 048 \\
\hline \multirow[t]{2}{*}{8} & \multicolumn{5}{|c|}{ 専門分野を超えた技術, 知識, 経験の共有の場がある } \\
\hline & .361 & .171 & .105 & .032 & .182 \\
\hline \multirow[t]{2}{*}{9} & \multicolumn{5}{|c|}{$\begin{array}{l}\text { プロジェクト遂行の標準手順（プロセジャ一）が整備 } \\
\text { されている }\end{array}$} \\
\hline & .097 & .799 & .025 & -.015 & -.103 \\
\hline \multirow[t]{2}{*}{10} & \multicolumn{5}{|c|}{$\begin{array}{l}\text { 先輩エンジニアからプロジェクトマネジメントにつ } \\
\text { いて学ぶ機会がある }\end{array}$} \\
\hline & .303 & .682 & -.140 & .089 & -.178 \\
\hline \multirow[t]{2}{*}{11} & \multicolumn{5}{|c|}{$\begin{array}{l}\text { 十分な経験, 知識のあるプロジェクトマネージャがア } \\
\text { サインされている }\end{array}$} \\
\hline & .155 & .667 & .098 & -.158 & .065 \\
\hline \multirow[t]{2}{*}{12} & \multicolumn{5}{|c|}{$\begin{array}{l}\text { リスクを特定し定量評価するための手法を備えてい } \\
\text { る }\end{array}$} \\
\hline & .327 & .569 & -.044 & -. 139 & .123 \\
\hline \multirow[t]{2}{*}{13} & \multicolumn{5}{|c|}{$\begin{array}{l}\text { 設計や機材の品質を確実なものにするためのスケジ } \\
\text { ュール遅延は柔軟に調整できる }\end{array}$} \\
\hline & .149 & .530 & -.167 & .040 & .254 \\
\hline \multirow[t]{2}{*}{14} & \multicolumn{5}{|c|}{$\begin{array}{l}\text { プロジェクトマネージャはプロジェクトの状況, 課題 } \\
\text { をよく把握し, 対策のための指示を出している }\end{array}$} \\
\hline & -.162 & .516 & .325 & .018 & .151 \\
\hline \multirow[t]{2}{*}{15} & \multicolumn{5}{|c|}{ スコープの変更は関係者に迅速に伝えられる } \\
\hline & -.111 & .477 & .143 & .215 & .091 \\
\hline \multirow[t]{2}{*}{16} & \multicolumn{5}{|c|}{$\begin{array}{l}\text { プロジェクトマネジメントに関するナレッジデータ } \\
\text { ベースがプロジェクトメンバー間で共有されている }\end{array}$} \\
\hline & .307 & .369 & -.058 & -.010 & .290 \\
\hline \multirow[t]{2}{*}{17} & \multicolumn{5}{|c|}{$\begin{array}{l}\text { プロジェクト遂行計画が作成, 配布され, かつ遵守を } \\
\text { 促す仕組みがある }\end{array}$} \\
\hline & -.056 & .331 & .134 & .310 & .134 \\
\hline \multirow[t]{2}{*}{18} & \multicolumn{5}{|c|}{$\begin{array}{l}\text { 不測の事態の対策を講じる権限は特定のマネジメン } \\
\text { 卜層のみが持っている }\end{array}$} \\
\hline & .279 & -.107 & .740 & -.090 & -.042 \\
\hline \multirow[t]{2}{*}{19} & $\begin{array}{l}\text { プロジェy } \\
\text { ネジメント }\end{array}$ & $\begin{array}{l}\text { の規模 } \\
\text { かかる1 }\end{array}$ & $\begin{array}{l}\text { 祄比例 } \\
\text { が増加す }\end{array}$ & てプロシ & クトマ \\
\hline & -.179 & -.076 & .631 & .017 & .327 \\
\hline 20 & $\begin{array}{l}\text { ステーク } \\
\text { Delivery) }\end{array}$ & $\begin{array}{l}\text { ルダー } \\
\text { 重視の }\end{array}$ & $\begin{array}{l}の Q C D \\
\text { ルに差暜 }\end{array}$ & $\begin{array}{l}\text { Quality } \\
\text { ‘ある }\end{array}$ & Cost, \\
\hline & .217 & .182 & .582 & -. 165 & -.098 \\
\hline 21 & $\begin{array}{l}\text { プロジェク } \\
\text { ジェクト特 }\end{array}$ & 遂行の木 & 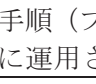 & $\begin{array}{l}\text { セジャー } \\
\text { る }\end{array}$ & はプロ \\
\hline & -.086 & .184 & .424 & .277 & .066 \\
\hline 22 & $\begin{array}{l}\text { ミーティン } \\
\text { 示が伝えら }\end{array}$ & る゙は主 & トジ & から0 & 络と指 \\
\hline & .056 & -.045 & .359 & .340 & .086 \\
\hline 23 & $\begin{array}{l}\text { 予算と実絸 } \\
\text { できる }\end{array}$ & 付比を & エク & ソバー| & 共有 \\
\hline & .005 & -.136 & -.045 & .906 & .063 \\
\hline 24 & $\begin{array}{l}\text { このプロシ } \\
\text { 能性のある }\end{array}$ & $\begin{array}{l}\text { クトの } \\
\text { 害を早 }\end{array}$ & $\begin{array}{l}\text { ジュ } \\
\text { 気付力 }\end{array}$ & $\begin{array}{l}\text { 亿影響を } \\
\text { 仕組み }\end{array}$ & $\begin{array}{l}\text { ぼす可 } \\
\text { 2る }\end{array}$ \\
\hline & .139 & .009 & -.114 & .828 & -.082 \\
\hline
\end{tabular}




\begin{tabular}{|c|c|c|c|c|c|}
\hline \multirow[t]{2}{*}{25} & \multicolumn{5}{|c|}{$\begin{array}{l}\text { スコープ定義に基づいた WBS（Work } \text { Breakdown } \\
\text { Structure）が作成され，共有されている }\end{array}$} \\
\hline & 246 & 120 & .067 & .485 & -.063 \\
\hline \multirow[t]{2}{*}{26} & \multicolumn{5}{|c|}{ 人的資源の調整のための手段と仕組みを備えている } \\
\hline & .207 & .040 & .164 & .447 & -.015 \\
\hline \multirow[t]{2}{*}{27} & \multicolumn{5}{|c|}{$\begin{array}{l}\text { 様々な変更がスケジュールに及ぼす影響度合いを事 } \\
\text { 前に把握できる }\end{array}$} \\
\hline & -.072 & .300 & .084 & 407 & .156 \\
\hline \multirow[t]{2}{*}{28} & \multicolumn{5}{|c|}{$\begin{array}{l}\text { プロジェクトのデータはステークホルダー間で共有 } \\
\text { されている }\end{array}$} \\
\hline & .174 & .085 & .156 & 370 & .043 \\
\hline \multirow[t]{2}{*}{29} & \multicolumn{5}{|c|}{$\begin{array}{l}\text { スケジュール, コストなどについての目標が設定され } \\
\text { ている }\end{array}$} \\
\hline & -.209 & .052 & .160 & -.021 & .749 \\
\hline \multirow[t]{2}{*}{30} & \multicolumn{5}{|c|}{$\begin{array}{l}\text { 技術に関寸るナレッジデータベースがプロジェクト } \\
\text { メンバー間で共有されている }\end{array}$} \\
\hline & .345 & -.130 & .024 & .027 & .676 \\
\hline \multirow[t]{2}{*}{31} & \multicolumn{5}{|c|}{ ミーティングでは主に出席者による議論が行われる } \\
\hline & .179 & .063 & -.083 & 173 & .382 \\
\hline \multirow[t]{2}{*}{32} & \multicolumn{5}{|c|}{$\begin{array}{l}\text { プロジェクトの意義や価值がステークホルダー間で } \\
\text { 共有され，実現のため互いに協力している }\end{array}$} \\
\hline & .246 & .146 & -.066 & .073 & .377 \\
\hline \multirow[t]{2}{*}{33} & \multicolumn{5}{|c|}{$\begin{array}{l}\text { 状況を監視し, 不測の事態に際してはすぐに相談でき } \\
\text { る人や組織が存在する }\end{array}$} \\
\hline & .286 & .252 & -.069 & .043 & .322 \\
\hline \multirow[t]{2}{*}{34} & \multicolumn{5}{|c|}{$\begin{array}{l}\text { 見積り（コスト, スケジュール, 課題の抽出）は合理 } \\
\text { 的である }\end{array}$} \\
\hline & .202 & .171 & .172 & -.096 & .317 \\
\hline
\end{tabular}

\subsection{2 アンケートの実施}

調查対象は産業施設建設のプロジェクトマネジメント経験者とし た。調查にはミクシィ・リサーチ社を利用した。アンケート調查方 法の詳細については表 3 に示寸。304 件の有効な回答については, 表 4 に示す通り, 平均年齢 48.8 歳で, 40 代と 50 代で全体の $70 \%$ を 占める。また, 表 5 に示す通り, プロジェクトマネジメント経験年 数は 10 年未満が $47 \%, 20$ 年未満が累積で $80.9 \%$ あるる。残りの $19.1 \%$ は経験が 20 年以上のベテランであり，各層からの回答が得られた。 回答者の属性は, オーナー側と受注側の比率が $62.5: 37.5$ とオーナ 一企業に勤める方の回答が多かったが，概社両方の立場から回答が 得られたと言える。受注者側の回答者の業種は, エンジニアリング 専業が $22.4 \%$ ，総合建設が $42 \%$ と大多数を占める。

Table3 Response of Internet questionnaire

\begin{tabular}{|l|l|}
\hline 調査日時 & 2014 年 11 月 21 日 26 日 \\
\hline 回収数 & 500 件 \\
\hline 有効回答数 & 304 件 \\
\hline \multicolumn{2}{|l|}{ 無効回答としての判断基準 } \\
\hline 1 & 6 件法の設問に同番号で回答 (75\%以上) \\
\hline 2 & 6 件法の設問に対し連番で回答 (不真面目) \\
\hline 3 & $\begin{array}{l}\text { 「組織のマインドフルな行動」に関する質問 (15 問) に } \\
\text { 対し同番号で回答 (100\%) }\end{array}$ \\
\hline 4 & 明らかに不真面目な回答（自由記述） \\
\hline 5 & 経験年数と年齢の不整合 \\
\hline
\end{tabular}

Table4 Distribution of responses (Age)

\begin{tabular}{|c|c|c|}
\hline 年齢 & 度数 & 割合 \\
\hline 20 代 & 6 & 2.0 \\
\hline 30 代 & 42 & 13.8 \\
\hline 40 代 & 108 & 35.5 \\
\hline 50 代 & 105 & 34.5 \\
\hline 60 代以上 & 43 & 14.1 \\
\hline
\end{tabular}

Table5 Distribution of responses (Experience)

\begin{tabular}{|c|c|c|}
\hline 経験年数 & 度数 & 割合 \\
\hline 5 年未満 & 74 & 24.3 \\
\hline $5 \sim 10$ 年未満 & 69 & 22.7 \\
\hline $10 \sim 15$ 年未満 & 58 & 19.1 \\
\hline $15 \sim 20$ 年未満 & 45 & 14.8 \\
\hline $20 \sim 25$ 年未満 & 27 & 8.9 \\
\hline 25 年以上 & 31 & 10.2 \\
\hline
\end{tabular}

\section{2 アンケート分析}

\section{2 .1 変数の合成と因子分析}

データ分析の事前準備として,「プロジェクトの成否」を尋ねる 4 設問,「組織のレジリエンス」を尋衩る 4 設問, 「組織のマインドフ ルな行動」を尋ねる 15 設問をそれぞれ 1 つの目的変数にまとめた。 目的変数の合成に際し, 合成の可否を確認寸るために信頼性分析を 実施した。信頼性分析には $\alpha$ 係数を用いた。

プロジェクトの成否は, 求められる品質, コスト, 納期の達成を 統合して考えるべきであることから 4 つの設問を 1 つの変数として 扱うこととした。4 設問の信頼性分析の結果はCronbachの $\alpha .867$ で あった。したがって内的整合性は十分であると判断し，4 設問の回 答の平均值を目的変数：「プロジェクトの成否」とした.

プロジェクト組織のレジリェンスは, 不測の事態, および顕在化 したリスクがコストとスケジュールに与える影響を統合して考える べきであることから 4 つの設問を 1 つの変数として扱うこととした。 信頼性分析の結果は Cronbach の $\alpha .770$ であったが，不測の事態の 発生の有無を問う 1 設問を削除すると $\alpha .822$ と上昇したので, この 1 設問を除いた 3 設問の回答の平均值を目的変数 :「組織のレジリエ ンス」とした。

「組織のマインドフルな行動」を問う 15 設問の信頼性分析の結 果は Cronbachの $\alpha .935$ であった。したがって内的整合性は高いと 判断し, 15 設問の回答の平均值を目的変数:「組織のマインドフル な行動」とした. 組織のマインドフルな行動は, Weick らの述べる 5 つの特徴（失敗から学ぶ，単純化を許さない，操業の現場を重視す る, 復旧能力を高める, 専門知識を尊重する）を統合して付けた名 称であることから，合成した変数の方が関連性を示すのに相応しい と考え, 1 つの変数として扱うこととした。アンケート調查票の設 問はこの 5 つの特徴を網羅するものとした。

また，「プロジェクトマネジメント施策」は 35 問という多数の変 数で構成されるため, 因子分析を用いて説明変数となる共通因子を 抽出した。分析にはSPSS Statistics 22 を利用した。十分な因子負 荷量を示さなかった 1 項目を分析から除外後, 最尤法・Promax 回転 
による因子分析を行った結果, 採用した因子の固有值を示す (表 6)。

Table6 Factor scores

\begin{tabular}{|c|c|c|c|}
\hline 因子 & 固有值 & 寄与率 $(\%)$ & 累積寄与率 $(\%)$ \\
\hline 1 & 16.128 & 47.434 & 47.434 \\
\hline 2 & 1.775 & 5.222 & 52.656 \\
\hline 3 & 1.358 & 3.994 & 56.650 \\
\hline 4 & 1.069 & 3.143 & 59.793 \\
\hline 5 & 1.020 & 2.999 & 62.793 \\
\hline
\end{tabular}

第 1 因子は 8 項目で構成されており「多様性の活用」因子と命名し た。第 2 因子は 9 項目で構成されており「PMT の指導力発揮」因子 と命名した。第 3 因子は 5 項目で構成されており「トップダウンで の意思決定」因子と命名した。第 4 因子は 6 項目で構成されており 「潜在的リスクの早期察知」因子と命名した。第 5 因子は 6 項目で 構成されており「協力の促進」因子と命名した。

\section{2 .2 仮説の確認}

プラント建設プロジェクト遂行に関与する組織のマインドフルな 行動がプロジェクト遂行における組織のレジリエンスに影響を与え ていることを確認するために, 説明変数を「組織のマインドフルな 行動」,目的変数を「組織のレジリエンス」として回帰分析を行った。 この結果調整済み決定係数は. 392 で，0.1\%水準で有意となった（表 7)。したがって,「組織のマインドフルな行動」が「組織のレジリエ ンス」に影響を与えていると判断できる。

Table7 Result of regression analysis

\begin{tabular}{|c|c|c|c|}
\hline $\mathrm{R}$ & $\mathrm{R} 2$ 乗 & 調整済 R2 乗 & 有意確率 \\
\hline 0.627 & 0.394 & 0.392 & 0.000 \\
\hline & 係数 $\beta$ & 標準化係数 $\beta$ & 有意確率 \\
\hline $\begin{array}{c}\text { 組織のマイン } \\
\text { ドフルな行動 }\end{array}$ & 0.769 & 0.627 & 0.000 \\
\hline
\end{tabular}

プロジェクトマネジメント施策がプロジェクト遂行に関与する組 織のマインドフルな行動に影響を与えることを確認するために, 説 明変数を「プロジェクトマネジメント施策の全ての因子」, 目的変数 を「組織のマインドフルな行動」とし, 強制投入法により重回帰分 析を行った。その結果, 調整済み決定係数は. 702 であり, $0.1 \%$ 水準 で有意であった（表 8)。したがって, 組織のマインドフルな行動に 対してプロジェクトマネジメント施策の全ての因子が影響を与えて いると判断できる。

Table8 Result of multiple regression analysis

\begin{tabular}{|l|c|c|c|}
\hline \multicolumn{1}{|c|}{$\mathrm{R}$} & $\mathrm{R} 2$ 乗 & 調整済 R2 乗 & 有意確率 \\
\hline 0.841 & 0.707 & 0.702 & 0.000 \\
\hline & 係数 $\beta$ & 標準化係数 $\beta$ & 有意確率 \\
\hline 多様性の活用 & -.145 & -.154 & .008 \\
\hline PMT の指導力発揮 & .212 & .222 & .001 \\
\hline $\begin{array}{l}\text { トップダウンでの意思 } \\
\text { 決定 }\end{array}$ & .158 & .151 & .001 \\
\hline $\begin{array}{l}\text { 潜在的リスクの早期察 } \\
\text { 知 }\end{array}$ & .393 & .417 & .000 \\
\hline 協力の促進 & .330 & .277 & .000 \\
\hline
\end{tabular}

5 つのプロジェクトマネジメント施策の因子と, 組織のマインド フルな行動の相関関係を確認すると， 3 つの施策「PMT の指導力発 揮」「潜在的リスクの早期察知」「協力の促進」と「組織のマインド フルな行動」の間に非常に強い相関が見られる（表 9)。

Table9 Correlation coefficient

\begin{tabular}{|c|c|}
\hline \multirow{2}{*}{ 多様性の活用 } & $\begin{array}{c}\text { 組織のマインドフルな行動 } \\
\text { (上段 : Pearsonの相関係数 } \\
\text { 下段 : 有意確率 (両側) })\end{array}$ \\
\cline { 2 - 2 } & 0.650 \\
\hline \multirow{2}{*}{ PMT の指導力発揮 } & 0.000 \\
\cline { 2 - 2 } & 0.761 \\
\hline \multirow{2}{*}{$\begin{array}{c}\text { トップダウンでの } \\
\text { 意思決定 }\end{array}$} & 0.000 \\
\hline 潜在的リスクの & 0.664 \\
\hline 早期察知 & 0.000 \\
\cline { 2 - 2 } & 0.790 \\
\hline \multirow{2}{*}{ 協力の促進 } & 0.000 \\
\cline { 2 - 2 } & 0.751 \\
\hline
\end{tabular}

最後に, 組織のレジリエンスとプロジェクトの成否の関係を確認 するため, 説明変数を「組織のレジリエンス」, 目的変数を「プロジ エクトの成否」として回帰分析を行った。この結果, 調整済み決定 係数は. 475 で，0.1\%水準で有意となった（表 10）。

Table10 Result of regression analysis

\begin{tabular}{|c|c|c|c|}
\hline $\mathrm{R}$ & $\mathrm{R} 2$ 乗 & 調整済 R2 乗 & 有意確率 \\
\hline 0.691 & 0.477 & 0.475 & 0.000 \\
\hline & 係数 $\beta$ & 標準化係数 $\beta$ & 有意確率 \\
\hline レジリエンス & 0.702 & 0.691 & 0.000 \\
\hline
\end{tabular}

以上より，本研究の仮説である「プロジェクトマネジメントの施 策がプロジェクト遂行組織のマインドフルな行動を促進するもので あれば，失敗するかもしれないリスクを多く抱えるプロジェクトで あっても組織のレジリエンスを駆使して成功に導くことが可能であ る」という関係が定量的に有意であることが示された。

\section{3 属性の差に基づく分析}

更に, プロジェクトの性格, 組織編成等の違いがプロジェクトマ ネジメント施策の組織のマインドフルな行動にどのような影響を与 えるか確認するために, プロジェクトマネジメント経験年数の違い, 立場（オーナ一側か受注者側か）の違い, 組織編成（JV か一社単独 か）の違いによるケースで重回帰分析を実施した。

表 11，12，13，14 はプロジェクトマネジメント経験年数の違いに よる影響を示している。経験年数 5 年未満のグループに対する分析 では共線性の統計量におけるVIF（Variance Inflation Factor）が 高くなったので評価対象から外した。経験が 5 年以上 15 年未満の グループは「PMT の指導力発揮」が有意となった。すなわち, 自分達 が前面に立ってリーダーシップを発揮し，プロジェクトを成功に導 こうとしている姿を描くことができる。経験が 15 年以上のグルー 
プは「協力の促進」が有意となった。すなわち, 自分達が前面に出 るのではなく, プロジェクトに関与している組織や個人がパフォー マンス(注 6)を発揮できるよう取り計らう姿を描くことができる。

Table11 Project management experience with $5-9$ years

\begin{tabular}{|l|c|c|c|}
\hline \multicolumn{1}{|c|}{$\mathrm{R}$} & $\mathrm{R} 2$ 乗 & 調整済 R2 乗 & 有意確率 \\
\hline 0.885 & 0.784 & 0.767 & 0.000 \\
\hline 多様性の活用 & 係数 $\beta$ & 標準化係数 $\beta$ & 有意確率 \\
\hline PMT の指導力発揮 & -.151 & -.184 & .144 \\
\hline $\begin{array}{l}\text { トップダウンでの意思 } \\
\text { 決定 }\end{array}$ & .436 & .461 & .004 \\
\hline $\begin{array}{l}\text { 潜在的リスクの早期察 } \\
\text { 知 }\end{array}$ & .336 & .071 & .447 \\
\hline 協力の促進 & .264 & .373 & .001 \\
\hline
\end{tabular}

Table12 Project management experience with $10-14$ years

\begin{tabular}{|l|c|c|c|}
\hline \multicolumn{1}{|c|}{$\mathrm{R}$} & $\mathrm{R} 2$ 乗 & 調整済 R2 乗 & 有意確率 \\
\hline 0.868 & 0.754 & 0.731 & 0.000 \\
\hline & 係数 $\beta$ & 標準化係数 $\beta$ & 有意確率 \\
\hline 多様性の活用 & -.086 & -.098 & .417 \\
\hline $\begin{array}{l}\text { PMT の指導力発揮 } \\
\text { トップダウンでの意思 } \\
\text { 決定 }\end{array}$ & .479 & .586 & .000 \\
\hline $\begin{array}{l}\text { 潜在的リスクの早期察 } \\
\text { 知 }\end{array}$ & -.022 & .316 & .001 \\
\hline 協力の促進 & .189 & .203 & .853 \\
\hline
\end{tabular}

Table13 Project management experience with $15-19$ years

\begin{tabular}{|l|c|c|c|}
\hline \multicolumn{1}{|c|}{$\mathrm{R}$} & $\mathrm{R} 2$ 乗 & 調整済 R2 乗 & 有意確率 \\
\hline 0.857 & 0.734 & 0.700 & 0.000 \\
\hline 多様性の活用 & 係数 $\beta$ & 標準化係数 $\beta$ & 有意確率 \\
\hline PMT の指導力発揮 & .214 & .251 & .103 \\
\hline $\begin{array}{l}\text { トップダウンでの意思 } \\
\text { 決定 }\end{array}$ & -.126 & -.140 & .342 \\
\hline $\begin{array}{l}\text { 潜在的リスクの早期察 } \\
\text { 知 }\end{array}$ & .263 & .166 & .124 \\
\hline 協力の促進 & .541 & .445 & .056 \\
\hline
\end{tabular}

Table14 Project management experience with 20 years or more

\begin{tabular}{|l|c|c|c|}
\hline \multicolumn{1}{|c|}{$\mathrm{R}$} & $\mathrm{R} 2$ 乗 & 調整済 R2 乗 & 有意確率 \\
\hline 0.717 & 0.514 & 0.467 & 0.000 \\
\hline 多様性の活用 & 係数 $\beta$ & 標準化係数 $\beta$ & 有意確率 \\
\hline PMT の指導力発揮 & -.156 & -.156 & .337 \\
\hline $\begin{array}{l}\text { トップダウンでの意思 } \\
\text { 決定 }\end{array}$ & -.075 & -.075 & .694 \\
\hline $\begin{array}{l}\text { 潜在的リスクの早期察 } \\
\text { 知 }\end{array}$ & .482 & .051 & .741 \\
\hline 協力の促進 & .584 & .472 & .017 \\
\hline
\end{tabular}

表 15，16 はプロジェクトに関わる立場（オーナー側か受注者側 か）の違いによる影響を示している。「トップダウンでの意思決定」 はオーナー側だけで有意となっている。すなわちオーナー側は組織 がマインドフルに行動し, 契約通りの納期, 品質, コストを満たす ためにトップダウンでの意思決定が重要であると評価している。こ の場合のトップダウンとは「会社の方針に沿った」と言い換えられ
るだろう。また, 受注者側において「潜在的リスクの早期察知」の 標準化係数值が高く, リスク管理役務が契約に含まれることが推察 されるとともに，その状況がマインドフルな組織の醸成をもたらし ていると評価できる。

Table15 Result of multiple regression analysis for owner

\begin{tabular}{|l|c|c|c|}
\hline \multicolumn{1}{|c|}{$\mathrm{R}$} & $\mathrm{R} 2$ 乗 & 調整済 R2 乗 & 有意確率 \\
\hline 0.862 & 0.743 & 0.736 & 0.000 \\
\hline & 係数 $\beta$ & 標準化係数 $\beta$ & 有意確率 \\
\hline 多様性の活用 & -.120 & .063 & .056 \\
\hline PMT の指導力発揮 & .175 & .072 & .016 \\
\hline $\begin{array}{l}\text { トップダウンでの意思 } \\
\text { 決定 }\end{array}$ & .174 & .054 & .001 \\
\hline $\begin{array}{l}\text { 潜在的リスクの早期察 } \\
\text { 知 }\end{array}$ & .397 & .069 & .000 \\
\hline 協力の促進 & .358 & .076 & .000 \\
\hline
\end{tabular}

Table16 Result of multiple regression analysis for contractor

\begin{tabular}{|l|c|c|c|}
\hline \multicolumn{1}{|c|}{$\mathrm{R}$} & $\mathrm{R} 2$ 乗 & 調整済 R2 乗 & 有意確率 \\
\hline 0.812 & 0.659 & 0.643 & 0.000 \\
\hline & 係数 $\beta$ & 標準化係数 $\beta$ & 有意確率 \\
\hline 多様性の活用 & -.172 & -.184 & .092 \\
\hline PMT の指導力発揮 & .279 & .292 & .019 \\
\hline $\begin{array}{l}\text { トップダウンでの意思 } \\
\text { 決定 }\end{array}$ & .109 & .105 & .264 \\
\hline $\begin{array}{l}\text { 潜在的リスクの早期察 } \\
\text { 知 }\end{array}$ & .395 & .406 & .000 \\
\hline 協力の促進 & .296 & .243 & .037 \\
\hline
\end{tabular}

表 17, 18 はプロジェクト遂行の組織編成の違い（JV か一社単独 か）による影響を示している。JVにおける「潜在的リスクの早期察 知」の標準化係数值が高く, JV でのプロジェクト遂行ではリスク管 理の重要性が明らかになった。

Table17 Project execution by JV

\begin{tabular}{|l|c|c|c|}
\hline \multicolumn{1}{|c|}{$\mathrm{R}$} & $\mathrm{R} 2$ 乗 & 調整済 R2 乗 & 有意確率 \\
\hline 0.870 & 0.756 & 0.747 & 0.000 \\
\hline & 係数 $\beta$ & 標準化係数 $\beta$ & 有意確率 \\
\hline 多様性の活用 & -.148 & -.153 & .145 \\
\hline PMT の指導力発揮 & .257 & .257 & .009 \\
\hline $\begin{array}{l}\text { トップダウンでの意思 } \\
\text { 決定 }\end{array}$ & -.000 & -.000 & .999 \\
\hline $\begin{array}{l}\text { 潜在的リスクの早期察 } \\
\text { 知 }\end{array}$ & .599 & .615 & .000 \\
\hline 協力の促進 & .228 & .189 & .043 \\
\hline
\end{tabular}

Table18 Project execution by a sole contractor

\begin{tabular}{|l|c|c|c|}
\hline \multicolumn{1}{|c|}{$\mathrm{R}$} & $\mathrm{R} 2$ 乗 & 調整済 R2 乗 & 有意確率 \\
\hline 0.823 & 0.678 & 0.668 & 0.000 \\
\hline 多様性の活用 & 係数 $\beta$ & 標準化係数 $\beta$ & 有意確率 \\
\hline PMT の指導力発揮 & -.139 & -.148 & .035 \\
\hline $\begin{array}{l}\text { トップダウンでの意思 } \\
\text { 決定 }\end{array}$ & .211 & .231 & .009 \\
\hline $\begin{array}{l}\text { 潜在的リスクの早期察 } \\
\text { 知 }\end{array}$ & .226 & .220 & .000 \\
\hline 協力の促進 & .377 & .299 & .000 \\
\hline
\end{tabular}


3.4 アンケートの自由記述回答分析

アンケートには回答者の経験や思いを収集し統計分析の結果を補 完する目的で自由記述の質問を設けた。

質問 1 : プロジェクトの成功のために重要なこと

質問 2 : 成功へのモチベーションが高まるきっかけ

質問 3 : 緊急対応時に意外と効果のあった施策

質問 1 に対する上位 5 分類の回答を表 19 に示す。これより, 個人 のモチベーションを高めメンバー間の協力を促すことが重要である ことが分かる。JarvenPaa ら 4) は, 複数拠点にまたがる組織におけ るコミュニケーションと信頼が時間軸で変化することを示し, 道具 よりも文脈，全体の仕組み，タイミングが重要であると主張する。 正しい意思決定のためには最新の情報の共有が必要であるが，関与 する人が多く, かつ複数の拠点で活動している場合, 情報共有を確 実で効果的なものとする仕組みも重要となるだろう。

Table19 Top 5 answers for question 1

\begin{tabular}{|l|c|}
\hline \multicolumn{1}{|c|}{ 回答の分類 } & 回答数 \\
\hline 個人のモチベーション, 熱意 & 59 \\
\hline 協力, チームワーク & 58 \\
\hline 信頼関係 & 20 \\
\hline 意思決定, リーダーシップ & 18 \\
\hline 情報共有 & 18 \\
\hline
\end{tabular}

質問 2 に対する上位 5 分類の回答を表 20 に示す。プロジェクト メンバーは個人の達成感を実感できることを重視している事が分か る。また,他者から自分への評価もモチベーションに影響を与える。 プロジェクト環境とは, プロジェクトの目標, 及び目標達成のため に為すべきことが明確に示されていることである。

Table20 Top 5 answers for question 2

\begin{tabular}{|l|c|}
\hline \multicolumn{1}{|c|}{ 回答の分類 } & 回答数 \\
\hline 自己実現 & 79 \\
\hline チームワーク & 57 \\
\hline 金銭的報酬 & 38 \\
\hline プロジェクト環境 & 34 \\
\hline 評価を得ること & 28 \\
\hline
\end{tabular}

質問 3 に対する上位 5 分類の回答を表 21 に示す。コミュニケー ションを伴う協力の具体例として, 情報交換や議論など, 複数の人 が一緒に検討することの効果が挙げられた。また, 事前に緊急事態 を想定し, 日頃のトレーニングにより体を慣らしておくことの重要 性も挙げられた。

Grabowski ら 5)は, リスクを低く抑える組織は個人間の信頼を築 くために非常に多様で多くの施策を取り入れており，それら施策は 個人間の協力を促し組織間の連携を強化するトレーニングの形を取 る場合があると述べる。トレーニングは頭で考えるだけでは完全に 想定できない他の組織やメンバーの判断や行動, 自分の弱みを体感 することができるので，施策をプロジェクト毎に実践的なものとす るのに効果がある。迅速な対応には「その場を見ること」を重視す
る意見も含まれる。緊急事態の意思決定のスピードを上げるには権 限を適切な人に委諘すると良いケースがある。権限委譲は, 平常時 には権限を持たない若手や現場の人に対して行われるだけでなく， 上位者に判断を委祆るケースも含まれる。

Table21 Top 5 answers for question 3

\begin{tabular}{|l|c|}
\hline \multicolumn{1}{|c|}{ 回答の分類 } & 回答数 \\
\hline コミュニケーションを伴う協力 & 60 \\
\hline 事前の準備, 日頃のトレーニング & 34 \\
\hline 冷静な判断と対応 & 23 \\
\hline 迅速な対応 & 21 \\
\hline 上位者の介入, 権限委譲 & 20 \\
\hline
\end{tabular}

\section{5 インタビュー調査結果分析 \\ 3.5.1 インタビューの目的}

統計分析の結果を具体的事例と照らし合わせることにより分析結 果の妥当性を確認するため, プロジェクトマネジメント経験者 5 名 に，プロジェクトのスムーズな遂行に対する下記の影響についてイ ンタビューを実施した。

・PMT の指導力発揮

・ 潜在的リスクの早期察知

·協力の促進

·多様性の活用

\subsection{2 インタビューの結果分析}

PMT の指導力発揮について, PMT メンバー(注 7)の経験やプロジェ クトメンバーのパフォーマンスを引き出すための権限委譲, オーナ 一側を含むプロジェクトに関与する組織や人の意識の方向性を合わ せることの重要性が挙げられた。

潜在的リスクの早期察知はプロジェクトメンバーの人間性や能力 の影響を受ける場合があるので，PMT からメンバーに声をかけて， 思っていることを引き出す努力をすること，実際に現場や装置を見 ること, 過去の失敗経験に照らし合わせて考えることの重要性が挙 げられた。

協力の促進について, PMT メンバーがプロジェクトの成果を挙げ ることに注力し，指導力を発揮すること，互いに感謝の意を示すこ と, 組織間のコミュニケーションの際には互いのメンバーの職務上 の地位を合わせることの重要性が挙げられた。

多様性の活用について, 関わる国の文化を理解すること, 感情的 にならないこと，自分の常識だけで判断しないこと，多様性を当た り前のものとして捉えることの重要性が挙げられた。多様性一の対 応のために, PMT メンバーの業務経歴が多様であると様々な課題に 対応し易いという意見もあった。

インタビュー結果より，プロジェクトの成功にはプロジェクトに 関与するメンバーが，オーナー側，受注者側によらず，同じプロジ エクトを遂行する者として力を合わせることが重要であることが見 出された。そのために PMT は皆が目指寸べき目標を提示し，プロジ エクトメンバーの意識の方向性を合わせる必要がある。

また，PMT にはプロジェクトメンバーが 100\%の力を発揮できるよ うな環境を作ることも重要である。他のプロジェクトメンバーの業 
務経歴や立場，プロジェクトを遂行する他国の文化などを理解し， 互いに敬意を払いつつ意思疎通が図れるよう, プロジェクトメンバ 一が一堂に会する場を定期的に設けることや，プロジェクトメンバ 一が困っているようであれば尋㸚ること，その行動を認め，集める ことなどが求められる。データの集中管理や頻繁なリスクの見直し によって, プロジェクト遂行中の問題やリスクを早く掴み, プロジ エクトメンバーの懸念をできるだけ早く解消寸る事も重要である。 他方, PMT にはメンバーの失敗を許す度量が求められる。

\section{6 共分散構造分析}

プロジェクトマネジメント施策の構造を確認するために共分散構 造分析 (SEM : Structural Equation Modeling) を行った。分析には Amos22 を利用した。モデルの適合度合いを示寸指標を確認しながら 見直しを行い, SEM の評価指標が十分な值を示し (表 22), 定量的に 成立する事が示唆されるモデルを作成した（図 3)。また, 全ての観 測変数間 (図中の矢印の関係) の標準化推定值は有意であり (表 23), モデルから削除するべき観測変数は存在しないと判断した。

共分散構造分析により, 本研究の仮説である「組織のマインドフ ルな行動の促進と組織のレジリエンス発揮を通したプロジェクトの 成否の改善」には, 因子分析から得られた以下の 3 つのプロジェク トマネジメント施策を強化することが効果的であることが分かった。 また，組織のマインドフルな行動は組織のレジリエンスを経由しな くてもプロジェクトの成功に寄与することが示された。

\section{施策 $1 「$ PMT の指導力発揮」}

施策 2 「協力の促進」

施策 3 「潜在的リスクの早期察知」

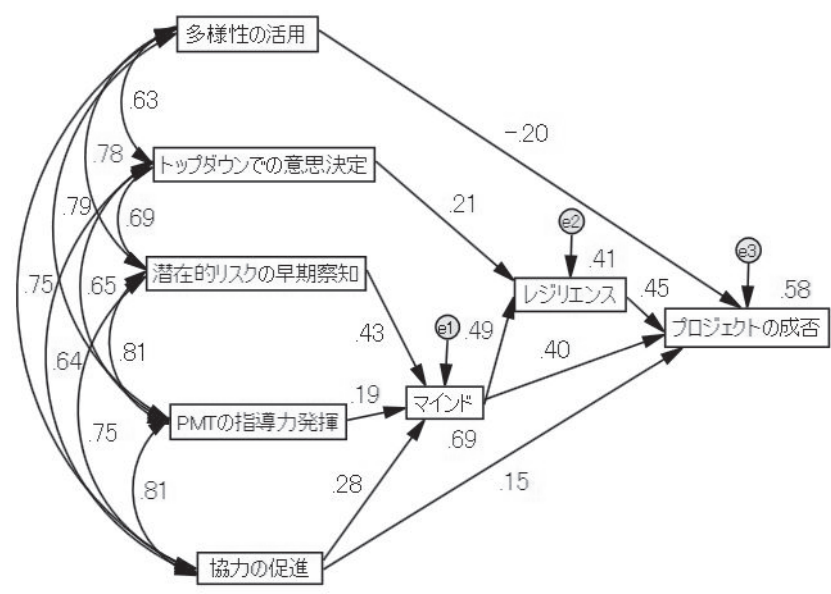

Fig.3 Structural equation modeling

また，本研究の仮説とは異なるパスも見出された。

「トップダウンでの意思決定」のための施策が取られると「組織 のレジリエンス」が向上する。何らかの急を要する対応が必要とな った場合等では, トップダウンで直接的にアクションを指示する方 法も有効であると解釈できる。

「多様性の活用」がプロジェクトの成功に対して負の影響,「協力 の促進」が正の影響を与えることが確認できた。多様な見解がある 事はリスク管理の上で良い面もあるだろうが，プロジェクト遂行に おいては多くの課題を伴うことが分かる。他方, 組織やメンバー間
の協力を促す施策はプロジェクトの成功に高い貢献が期待できる。

Table22 Index of structural equation modeling

\begin{tabular}{|c|c|c|c|c|c|}
\hline カイ二乗 & 自由度 & 有意確率 & GFI & AGFI & RMSEA \\
\hline 23.043 & 9 & 0.006 & 0.982 & 0.927 & 0.072 \\
\hline
\end{tabular}

Table23 Standardized estimates （***は $0.1 \%$ 水準で有意であることを示す）

\begin{tabular}{|c|c|c|c|c|}
\hline & & & $\begin{array}{l}\text { 標淮化 } \\
\text { 推定值 }\end{array}$ & 確率 \\
\hline $\begin{array}{l}\text { 組織のマインドフル } \\
\text { な行動 }\end{array}$ & $<$ & 協力の促進 & 0.276 & *** \\
\hline $\begin{array}{l}\text { 組織のマインドフル } \\
\text { な行動 }\end{array}$ & $<$ & $\begin{array}{l}\text { 潜在的リスクの } \\
\text { 早期察知 }\end{array}$ & 0.426 & $* * *$ \\
\hline $\begin{array}{l}\text { 組織のマインドフル } \\
\text { な行動 }\end{array}$ & $<$ & $\begin{array}{l}\text { PMT の指導力 } \\
\text { 発揮 }\end{array}$ & 0.193 & .002 \\
\hline レジリエンス & $<$ & $\begin{array}{l}\text { 組織のマインドフ } \\
\text { ルな行動 }\end{array}$ & 0.492 & $* * *$ \\
\hline レジリエンス & $<$ & $\begin{array}{l}\text { トップダウンでの } \\
\text { 意思決定 }\end{array}$ & 0.211 & $* * *$ \\
\hline プロジェクトの成否 & $<$ & レジリエンス & 0.452 & $* * *$ \\
\hline プロジェクトの成否 & $<$ & $\begin{array}{l}\text { 組織のマインドフ } \\
\text { ルな行動 } \\
\end{array}$ & 0.403 & $* * *$ \\
\hline プロジェクトの成否 & $<$ & 協力の促進 & 0.151 & .019 \\
\hline プロジェクトの成否 & $<$ & 多様性の活用 & -0.197 & $* * *$ \\
\hline
\end{tabular}

\section{4 考察}

アンケートの自由記述回答やインタビュー結果から, PMT による 指導力の発揮に対する期待が高いことが分かった。更に共分散構造 分析により, PMT による指導力の発揮がプロジェクトの成功に寄与 することを可視化することができた。Anantatmula 6) は，グローバ ルプロジェクトにおけるプロジェクトリーダーシップの形成, 文化 の相違に注意を払った信頼形成，情報システムの早期形成の重要性 を指摘する。複数の組織が関わることにより衝突や敬遠が発生し易 い状態であっても, PMT が適切に指導力を発揮することによって組 織のマインドフルな行動を促すことに寄与寸るだろう。

他方，プロジェクトマネジメント経験年数毎の統計分析結果は, 経験年数によって PMT メンバーの方針や指示に違いが出る可能性が あることを示した。すなわち, PMT メンバーの人選を慎重に行うこ との重要性が示唆されている。また, プロジェクトの遂行はダイナ ミックであり，開始からの時期により関与する組織や人が変わるの で, PMT はプロジェクトの半ばにもプロジェクトに関わる組織や人 のモチベーションを高め, 協力関係を築くための施策を実施し, 共 通の目標を見失わないようにする必要がある。

プロジェクトに関与する組織やメンバーの協力促進は，相対する 個人, 組織の意向を意識することにつながり, プロジェクトに関与 する組織のマインドフルな行動の促進に効果がある。共分散構造分 析は，本施策がプロジェクトの成功に直接貢献できるので注力す心゙ きであることを示した。各組織がプロジェクトに関与する他の組織 に期待できる技術や知見を把握し，また自らが発揮す心゙き専門性を 認識することによって，プロジェクトに関わる全組織が互いの技術 や知見を活用しながらパフォーマンスを最大限に発揮できる可能性 
がある。プロジェクトに関与する組織は, プロジェクトの成功以外 にも各組織としての目標がある。各組織の目標達成とプロジェクト の成功を共存させる施策を見出すためのコミュニケーションは結果 としてプロジェクトの成功確率を高めるのではないか。

Anantatmula 7) は, 文化的価值の多様性は作業の実行や生産性, プロジェクト管理の戦略に影響があり, プロジェクトマネージャは コミュニケーション計画や知識管理手順を構築する際に, 多様な文 化を考慮しなくてはならないと述べる。組織や個人の志向のみなら ず，それらが属する社会の背景まで考察することによりプロジェク 卜遂行中に採用寸心゙き施策が明らかになるのである。草柳 8) は「異 人種によって構成される国では, 様々な価值観や倫理観が存在し, 同じ言葉でも多くの解釈が生まれてくる。」と述べ, 国際建設プロジ エクトにおける文書での意思疎通の必要性を説く。文書には必要な 事が全て書き表されているとは限らないことに注意が必要であるが, プロジェクトメンバー間での共通認識のための記録としては価值が 高い。

プロジェクト遂行における潜在的リスクの早期察知は, マインド フルな行動に対する影響度が, 組織のマインドフルな行動に影響を 与える他の 2 つの施策よりも大きいので, 本施策にも注力すべきで ある。リスクの種に最も近い立場にいる “担当者”の声を拾い上げ る仕組みを取り入れることは問題の早期察知に効果があるのではな いか。但し, 担当者が情報発信し易い環境作りが欠かせない。すな わち, 担当者の作業量が増えたり, 担当者が不当に評価されたりし ないよう注意を払わなくてはならない。Morieux ら 9）は「助けを求 めた途端, それが遅延の真因だと言う信号を送ることになる」と述 べる。PMT は助けを求める者を責めるのではなく, サポートするこ とを表明することにより，リスクの早期察知を促すことができるの である。

また，リスク管理には過去の類似プロジェクトの事例を通して得 られた教訓を参照することが多いと思われるが，アンケートの自由 記述回答で得られた「日頃のトレーニング」と組み合わせることに より，プロジェクトに関わる組織や人に自律的な行動を促すような 効果的な活用が可能ではないだろうか。また, 現状はプロジェクト に関わる組織が個別に保有している教訓を共有することにより，当 該プロジェクトにおけるリスク管理の精度を上げられると考えられ る。したがって, 教訓を複数の組織で共有するための仕組み作りも 必要である。

共分散構造分析から，プロジェクトマネジメント施策 1 は，施策 $2 ， 3$ と相関が高いことが示された。すなわち，プロジェクトを成功 に導くプロジェクトマネジメント施策の実施のためには, PMT によ る適切な指導力の発揮が重要な役割を果たすことが分かる。

\section{5 おわりに}

本研究では, 多くの不確実性を抱える環境でのプラント建設プロ ジェクト遂行を成功させるために，プロジェクトマネジメントの施 策がプロジェクトに関わる組織のレジリエンスの向上につながるこ とをアンケート調查と統計分析によって立証した。

今後は, マインドフルな組織を作るのに効果的であると分かった 3 つの施策「PMT の指導力発揮」「協力の促進」「潜在的リスクの早期 察知」の具体化と効果測定が課題である。「協力の促進」については,
直接契約関係のある組織間, 及び直接契約関係はないが同一プロジ エクトに関与し一方の組織のパフォーマンスが他方の行動に影響を 与えるような組織間の協力という観点での分析を含む必要がある。

注

注 1) 当該プロジェクトに関わる人。プロジェクトマネジメント施策に従って プロジェクトの目的を達成するために，設計，調達，建設などの常設部門 に所属し，各種専門技術を用いて業務を行う。

注 2) 外部要因により物理的，機能的変化を強制された後，元の機能を取り戻 そうとする力

注 3) プロジェクトマネジメント施策の検討, 導入の決定, 実行に責任を持ち, プロジェクト全体をリードする組織

注 4) 元請の設計, 建設業務の一部を担う組織

注 5) Weick らは，高い信頼性を発揮する組織に共通して見られる「マインド フルネス」を「つ衩に心構えが高い状態を維持していること」と定義して いる。本論文では, Weick らがそのような組織から見出した 5 つの特徴を持 つ行動を「マインドフルな行動」と呼称することとした。

注 6) 業務遂行能力，あるいはその能力を発揮した結果

注 7) PMT に所属し，プロジェクトマネジメント業務を主務とする人

\section{参考文献}

1) Patricia H. Longstaff et al. : Building Resilient Communities: A Preliminary Framework for Assessment, HOMELAND SECURITY AFFAIRS, Vol. 6, No. 3, pp.1-23, 2010

2) Karl E. Weick, Kathleen M. Sutcliffe : 不確実性のマネジメント〜危機を 事前に防ぐマインドとシステムを構築する〜，ダイヤモンド社, 2002

3) Project Management Institute, Inc. : プロジェクトマネジメント知識体系 ガイド（PMBOK®ガイド）第 5 版, Project Management Institute, Inc., 2013

4) Sirkka L. Jarvenpaa, Prothy E. Leidner : Communication and Trust in Global Virtual Teams, Organization Science, Vol. 10, No. 6, pp.791-815, 1999

5) Martha Grabowski, Harlene H. Roberts : Risk Mitigation in Virtual Organizations, Organization Science, Vol. 10, No. 6, pp.704-721, 1999

6) Vittal S. Anantatmula : Impact of cultural differences on knowledge management in global projects, VINE, Vol. 40 No. 3/4, pp.239-253, 2010

7) Vittal S. Anantatmula : Managing Global Projects: A Structured Approach for Better Performance, Project Management Journal, Vol. 41, No. 2, pp.60-72, 2010

8）草柳俊二 : 国際建設プロジェクトのマネジメントシステム構築のための基 礎研究，土木学会論文集, No.546/VI-32, pp.101-112, 1996

9) Yves Morieux, Peter Tollman : 組織が動くシンプルな 6 つの原則一部門 の壁を越えて問題を解決する方法，ダイヤモンド社, 2014 


\title{
CORRELATION BETWEEN THE MEASURES OF PROJECT MANAGEMENT AND THE ENHANCEMENT OF RESILIENCE OF ORGANIZATION FOR THE SUCCESS OF PLANT CONSTRUCTION PROJECTS
}

\author{
Kazuhide $A B E^{*}$ and Kenichi TAKANO** \\ * Grad. Stud., Graduate School of System Design and Management, Keio University, M.System Design and Management \\ ** Prof., Graduate School of System Design and Management, Keio University, Dr.Eng.
}

This research aims to prove that the measures of project management lead the enhancement of resilience of organizations for the success of plant construction projects that entail a lot of risks due to their huge size and complicated formation of organizations.

This research covers the project management organizations that are relevant to the contract made between the owner and the main contractor, which may form a joint venture by some companies, and discuss the correlation between the measures of project management and the resilience of organizations on the main contractor's point of view.

For this aim, we made the hypothesis that some measures of project management make the people and organizations that are involved in a project attentive, and the attentiveness affects the resilience against unexpected events, and the resilience leads projects to success.

We sent the questionnaire to the people who have the experience of project management of plant construction projects and analyzed the result of the questionnaire statistically. The questionnaire consists of the questions that ask the result of project, the resilience of organizations, the attentiveness of organizations and the measures of project management in addition to the questions that ask the profiles of respondents and projects the respondents worked for

The result of multivariate analysis proved our hypothesis and showed five measures of project management that affect the success of plant construction projects. Those measures are (1) showing the leadership of project management team, (2) detecting potential risks as early as possible, (3) enhancing cooperation between organizations, (4) top-down decision making, and (5) utilizing diversity. Further, structural equation modeling (SEM) visualized the mutual relations between the success of projects, the resilience of organizations, the attentiveness of organizations and people, and five measures of project management. Especially, (1), (2) and (3) above followed the same path as our hypothesis. Open questions of Internet questionnaire and interviews with the people who are in charge of project management drew a lot of practical cases that support the result of this analysis.

The result of the statistical analysis and interviews shows the importance of the leadership of project management team, and the analysis conducted by the difference of experience of project management also shows the decision made by the team may be different depending on the experience of members who belong to the team. SEM revealed that enhancing cooperation between organizations can directly affect the success of projects. For this measure, it's important to know each company's respective goal and the diversity of culture. The use of documents is one of the effective ways to overcome diversity. Our statistical analysis also showed that detecting potential risks in an early stage has a big impact on the attentiveness of organizations. To develop a system to extract voices of the project members may assist to detecting potential risks effectively. Some responses to a free description question pointed out the effectiveness of usual training. Trainings with the knowledge that each company obtained from its past projects may make project members more attentive and may enhance the resilience of organizations.

There is a need for further research on early detection of risks and effective communication, because the ability to manage uncertainties which may arise during project has to be strengthened because of the increase of mega project, which usually brings more complexity and difficulties to project management organizations. 